\title{
Shuhbah Sebagai Komunikasi Terapeutik dalam Pembentukan Karakter
}

\author{
Hermansyah, Galuh Wiradinata \\ Bimbingan Peyuluhan Islam STID Sirnarasa \\ 27gwiradinta@gmail.com
}

\begin{abstract}
ABSTRAK
Shubbah merupakan suatu kegiatan yang rutin dilakukan oleh ikhwan setiap malam jum at dan jum at pagi kepada Mursyid Thoriqoh Qoddiriyah Naqsabanddiyah Pondok Pesantren Suryalaya (TQN PP Suryalaya) Syeikh Muhammad Abdul Gaos Saefulloh MaslulQS.yang berpusat di Pesantren Sirnarasa Ciceuri Desa Ciomas Kecamatan Panjalu Kabupaten Ciamis Jawa Barat. Penelitian ini bertujuan: (1) untuk mengetahui bagaimana Shubbah sebagai Komunikasi Terapeutik didalam pembentukan karakter; (2) untuk mengetabui Apa saja faktor pendukung dan penghambat pada pembentukan karakter Jama'ah Thoriqoh Qodiriyah Naqsabandiyab Pondok Pesantren Suryalaya di Pesantren Sirnarasa didalam Shubbah. Metode penelitian ini menggunakan kuantitatif dengan teknik populasi dan sampel, sedangkan data dihasilkan melalui observasi, wawancara dan angket selanjutnya dianalisis dengan pendekatan kuantitatif dan kualitatif. Lokasi yang menjadi objek penelitian ini adalah di Pesantren Sirnarasa Dusun Ciceuri, Desa Ciomas, Kecamatan Panjalu, Kabupaten Ciamis Jawa Barat. Hasil penelitian dapat simpulkan bahwa Shubbah memiliki semua komponen didalam komunikasi terapeutik, dan shubbah juga mampu membentuk karakter ikhwan jika ikhwan tersebut benar-benar memiliki keinginan untuk berubah. Adapun faktor pendukungnya adalab harus menjalankan tiga komponen shubbah yakni istima, Ijtima, dan i tiba. Dan faktor penghambatnya adalah tidak menjalankan benar-benar amaliyah yang telah dicontobkan Syeikh Mursyid.
\end{abstract}

Kata Kunci : Subbah, Thoriqot, Konseling

\section{ABSTRACT}

Shuhbah is an activity that is routinely carried out by ikhwan every Friday and Friday morning to Mursyid Thoriqoh Qoddiriyah Naqsabanddiyah Pondok Pesantren Suryalaya (TQN PP Suryalaya) Syeikh Muhammad Abdul Gaos Saefulloh Maslul QS. centered at the Sirnarasa Ciceuri Islamic Boarding School, Ciomas Village, Panjalu District, Ciamis Regency, West Java. This study aims: (1) to determine how the Shuhbah as a Therapeutic Communication in character building; (2) to find out what are the supporting and inhibiting factors in the formation of the character of the Jama'ah Thoriqoh Qodiriyah Naqsabandiyah 
Pondok Pesantren Suryalaya in the Sirnarasa Islamic Boarding School in the Shuhbah. This research method uses quantitative population and sample techniques, while the data is generated through observation, interviews and questionnaires and then analyzed using quantitative and qualitative approaches. The location that is the object of this research is the Sirnarasa Islamic Boarding School, Ciceuri Hamlet, Ciomas Village, Panjalu District, Ciamis Regency, West Java. The results of the study can be concluded that the Shuhbah has all the components in therapeutic communication, and that he is also able to form the character of the ikhwan if the brother really has the desire to change. The supporting factors are having to carry out the three components of the shuhbah, namely istima, Ijtima, and $i$ 'tiba. And the inhibiting factor is not actually practicing the amaliyah that Sheikh Murshid has exemplified.

Keywords: subbah, thoriqot, counseling

\section{PENDAHULUAN}

Karakter merupakan hal yang sangat penting bagi kehidupan suatu bangsa, sebab dengan memiliki karakter yang baik dan tangguh akan membentuk negara tersebut menjadi kuat, berintegritas dan memiliki moral yang baik. Jauh dari sifat-sifat tercela seperti misalnya akhlak yang buruk, melawan kepada orang tua atau tidak hormat kepada orang yang lebih tua dari usianya, selalu berbohong, angkuh bahkan hingga berani untuk mengambil hak rakyatnya sendiri jika dia adalah seorang pejabat.

Harian kompas memberitakan bahwa berdasarkan indeks persepsi korupsi, yang di laksanakan oleh lembaga survei Transparency Internasional, Indonesia masih masuk jajaran negara-negara Terkorup dengan menempati peringkat ke-118 dari 174 negara. Di harian yang sama, badan kehormatan DPR melaporkan ada 28 anggota dewan tersangkut masalah etika. Negara ini berada dalam krisis multi dimensional yang tak kunjung usai, kondisi diperburuk dengan krisis moral dan budi pekerti para pemimpin bangsa yang berimbas pada generasi muda.

Dari data di atas menunjukan bahwa negara Indonesia ini sedang mengalami krisis dalam bidang pembentukan karakter, yang mana pada kejadian akhir-akhir ini banyaknya kasus orang yang bunuh diri, orang yang angkuh bahkan mereka cenderung anarkis seperti halnya melakukan pengrusakan motor sendiri pada saat sedang ditilang oleh aparat penegak hukum. Belum lagi anak yang mempidanakan orang tuanya sendiri akibat kasus permasalahan hutang. Ini menunjukan bahwa bangsa Indonesia mesti memiliki karakter yang kuat dan karakter yang baik, dan harus sesuai dengan ajaran atau aturan yang berlandaskan Al-Qur'an dan hadist. 
Untuk menanggapi permasalahan karakter ini maka akan sangat diperlukan suatu media atau metode yang tepat agar permasalah ini benar-benar dapat terselesaikan secara maksimal, untuk menjadikan bangsa Indonesia yang bermartabat, kuat, dan baik dimata dunia. Ketika mengetahui permasalahan karakter ini timbul dari berbagai aspek seperti merajalelanya anak punk yang banyak menarik generasi remaja khususnya untuk berlaku hidup yang bebas namun dari berbagai aspek tersebut tidak sedikit dari bagian mereka yang ingin kembali lagi dan bertaubat menuju jalan yang benar.

Fakta di lapangan mengungkapkan untuk menuju perubahan tersebut tidaklah mudah dan cenderung sulit sebab tantangan dan cemoohan dari masyarakat sangatlah besar dan tidak sedikit juga masyarakat menganggap remeh mereka meski pada dasarnya mereka ingin berubah (wawancara peneliti dengan klien di inabah 2 putri). Di berbagai macam panti rehabilitasi pun tidak ada yang bisa menjamin kliennya untuk bisa pulih 100\%.

Di dalam bidang keilmuan bimbingan penyuluhan islam terdapat berbagai macam metode yang dapat digunakan baik melalui metode bimbingan, penyuluhan bahkan konseling dan juga terapi. Ada satu hal atau metode yang sangat menarik untuk dipelajari yakni adalah dengan menggunakan metode terapi dengan menggunakan pendekatan terapeutik.

Komunikasi terapeutik sendiri adalah komunikasi antara klien dan konselor yang mempunyai nilai-nilai penyembuhan dan akhirnya dapat mencapai tujuan konseling. Dalam hubungan tersebut klien merasa dihargai, diterima dan diarahkan. Dalam hubungan tersebut klien dapat meredakan ketegangan (katarsis), mengekspresikan perasaan dan pikiran, mengurangi beban psikologis bahkan menghilangkan sama sekali (Saam, 2014: 11). Adapun tujuan umum hubungan terapeutik menurut Stuart dan Sundeen (1987) adalah (a) kesadaran, penerimaan, dan penghargaan dari klien meningkat, (b) pemahaman identitas diri dan itegritas diri meningkat, (c) kemampuan membina hubungan akrab, interpendensi pribadi, keterampilan menerima dan memberi kasih sayang meningkat, dan (d) pemenuhan kebutuhan diri dan tujuan yang realistis juga meningkat. Melalui hubungan terapeutik klien merasa nyaman, lega dan dapat membentuk perilaku baru untuk pengembangan diri klien (Saam, 2014: 12).

Komunikasi terapeutik di Thoriqoh Qoddiriyah Naqsabanddiyah Pondok Pesantren Suryalaya (TQN PP Suryalaya) yang berpusat di pesantren Sirnarasa ada suatu kegiatan yang mana kegiatan itu dilakukan secara rutin pada hari kamis malam jum'at pada bada sholat isya hingga sekitar pukul 22.00 WIB, lalu dilanjut pada hari jum'at bada sholat subuh dan terkadang hingga waktu jum'at. Namun 
tak hanya pada hari itu saja dapat dilakukan shubbah, sebab dimana ada Mursyid itu juga bisa dikatakan bershubbah, dalam kalangan jama'ah atau ikhwan TQN PP Suryalaya di Pesantren Sirnarasa yang lebih sering dikatakan sebagai Shobbah. Pada kegiatan ini semua murid (klien) akan duduk dihadapan Syeikh Muhammad Abdul Gaos Saefulloh Maslul QS atau biasa dipanggil Abah Aos, beliau adalah Guru Mursyid dari TQN PP Suryalaya silsilah ke-38. Disini klien akan diberikan masukan oleh Abah Aos baik dengan menggunakan bahasa verbal maupun non verbal. Berdasarkan wawancara yang dilakukan terhadap Jama'ah atau biasa lebih akrab dikatakan ikhwan di kalangan murid Abah Aos, setelah melakukan Shubbah dapat dirasakan hati menjadi tenang, intensitas ibadah meningkat dan juga seperti menambah spirit dalam melakukan aktivitas baik aktivitas pekerjaan maupun ibadah.

Berdasarkan pemaparan di atas maka peneliti tertarik untuk meneliti lebih lanjut dan mendalam tentang Shuhbah sebagai komunikasi terapeutik didalam pembentukan karakter pada jama'ah Thoriqoh Qoddiriyah Naqsabanddiyah Pondok Pesantren Suryalaya Di Pesantren Sirnarasa Ciceuri Desa Ciomas Kecamatan Panjalu Kabupaten Ciamis.

Berdasarkan latar belakang di atas maka dapat dirumuskan masalah yang akan diteliti, yaitu: (1) Bagaimana shuhbah sebagai komunikasi terapeutik dalam membentuk karakter jama'ah Thoriqoh Qoddiriyah Naqsabanddiyah Pondok Pesantren Suryalaya di Pesantren Sirnarsa? (2) Apa faktor pendukung dan penghambat pada pembentukan karakter Jama'ah Thoriqoh Qoddiriyah Naqsabanddiyah Pondok Pesantren Suryalaya di Pesantren Sirnarasa didalam Shubbah?.

Metode yang digunakan dalam penelitian ini adalah metode Kuantitatif Deskriptif. Teknik yang digunakan yaitu teknik observasi, teknik wawancara, teknik angket, teknik pengelolaan data, dan teknik analisis data.

\section{LANDASAN TEORITIS}

Shubbah berasal dari kata Shabiba-yashhabu-shubbatan-shabaabatan-shaababa Hu yang artinya adalah bersahabat, berteman, berkawan (dengan dia), menemaninya mengawaninya (Yunus, 2013: 234). Sedangkan Shubah merupaka salah satu manhaj amaly dalam Islam, Argumen ini memiliki dasar yakni Hadits tentang subbab dan anjurannya. Dasar argumen ini wajib menurut ahli ilmu dan pemikir Abdul Wahhab As-Sya'roni dalam kitab Al-Anwar fii Adabi as-Shubbati 'inda al-Akbyar dasar argumen ini berdasarkan surat At-taubah ayat 119 (As-Sya'roni, 2007: 8). Shuhbah ialah metode berupa perbuatan yang menghantarkan kepada pensucian 
jiwa, mengosongkan diri dari kotoran dan kejelekannya, menghiasinya dengan kesempurnaan orang-orang sholeh. Dan dengannya menjadi bertakwalah hati seorang mukmin, dan bertambahlah keteguhannya di jalan Alloh (As-Sya'roni, 2007: 27).

Adapun orang yang benar disini adalah seorang syeikh mursyid yang memang ketetapan beliau dihadapan Alloh sudah ma'rifat seperti sabda Abah Aos "sepeninggalan Nabi Muhammad Sholallohu'alaihi wasalam, pengganti beliau itu bukan nabi buka rosul tetapi para ahli ma'rifat berdasarkan, "dan para ahli makrifat itu adalah para penggantiku [Wal'aarifuuna Nawwaabuun'annii]. Segala ucapan mereka, tindakan mereka, dan akhwal mereka tidak lain adalah ucapan, tindakan dan akwal kanjeng Nabi Muhammad. Risalah yang dibawa para pengganti Nabi yang hanya satu pada masanya ini ialah risalah nabi, hanya dengan pemahaman yang terbarukan [bifahmin jadid] sesuai tantangan dan kebutuhan umat pada zamannya (Hakim, 2017: 11).

Bahkan Manqobah 15 itu adalah tentang murid yang (Selalu) mendatangi guru, bukan guru yang mendatangi murid (Hakim, 2017: 90). Berikut adalah isi dari manqobah ke 15 yang sering dibacakan ketika kegiatan Manaqib berlangsung. "Diriwayatkan di dalam Kitab Haqooiqul Haqooiq: ada seorang perempuan menghadap Syeikh Abdul Qodir dan berkata: "Tuan saya ini punya anak hanya satu-satunya, sekarang tenggelam di lautan; adapun saya punya keyakinan bahwa Tuan bisa mengembalikan anak saya serta hidup. Syayyid Abdul Qodir berkata: "benar. Silahkan saja kembali, anakmu sudah ada dirumah". dari situ (dengan petunjuk Syeikh Abdul Qodir) perempuan itu segera kembali, ketika sampai dirumah, anaknya tidak ada. Segera ia menghadap Syayyid Abdul Qodir lagi sambil menangis dan menyatakan bahwa anaknya tidak ada di rumah. Kata Syayyid Abdul Qodir: "sekarang itu tentu sudah ada". perempuan itu segera kembali lagi kerumah dan anaknya tetap belum ada. semakin jadi dan memilukan tangisan perempuan itu kemudian menghadap Syayyid Abdul Qodir dengan penuh harap agar anaknya hidup lagi dan ada lagi. kemudian Syayyid Abdul Qodir menundukan kepala, setelah itu beliau berkata: "Sekarang tidak salah lagi bahwa anakmu sudah ada". perempuan itu segera kembali lagi kerumah, ketika sampai dirumah ternyata anaknya sudah ada serta selamat.

Dari situ (Atas kejadian ini) Syayyid Abdul Qodir munajat kepada Allah SWT. dan berkata: Saya merasa malu dengan perempuan tadi sampai tiga kali baru anaknya ada, mengapa terjadi demikian dan apa hikmahnya diperlambat sampai saya harus memikul malu dua kali. Firman Allah SWT perkataanmu kepada perempuan itu semuanya juga benar. Yang pertama menyebutkan ada itu benar, namun malaikat 
baru mengumpulkan jiwa raganya yang berserakan. Perkataanmu yang ke-dua juga benar namun baru lengkap anggota tubuhnya serta dihidupkan. Dan yang ketiga kalinya ketika perempuan itu sudah sampai dirumah, anaknya sudah diangkat dari lautan, dan didatangkan kerumahnya.

Kemudian Syayyid Abdul Qodir qs. munajat lagi dan berkata: Yaa Allah SWT. Engkau membuat makhluk yang tak terhingga tidak mendapat kesulitan, begitu pula di alam ba'asy mengumpulkan jiwa raga makhluk yang sangat banyak hanya sekajap nyata. Sedangkan dalam masalah ini hanya seorang hamba, Ya..Allah SWT. apa hikmahnya sampai lama sekali?. Firman Allah SWT.: "Abdul Qodir engkau jangan jadi sakit hati, sekarang silahkan segera minta, ingin apa? Tentu Aku kabulkan. Terus Syayyid Abdul Qodir bersujud dan berkata: Yaa Allah SWT. Engkau Kholik (yang membuat) sedangkan aku makhluk (yang dibuat) apapun pemberian-Mu aku sangat bersyukur. Firman Allah SWT.: siapapun yang melihatmu pada hari Jum'at akan Aku jadikan wali dan bila engkau melihat tanah tentu jadi emas. Kata Syayyid Abdul Qodir. Ya.. Allah keduanya itu juga kurang ada manfa'atnya bagiku setelah aku mati, aku memohon yang lebih agung dari itu dan tetap manfaatnya setelah aku mati. Firman Allah SWT. Namamu di jadikan seperti nama Kami dalam balasan atau ganjaran dan kemanjuranya, siapa yang membaca namamu pahalanya sama dengan membaca nama-Ku" (Ash Shiddiq, 2016: 150-152).

Imam Abu al-Qasim al-Qushariyah, seperti yang tercatat dalam kitab beliau alRisalah al-Qushayriyyah (1972), menjelaskan bahwa shuhbah terbagi kepada tiga jenis. Pertama, shuhbah dengan orang yang lebih tinggi kedudukannya. Maka ia sebenarnya lebih merupakan suatu khidmat (pengabdian). Kedua, shuhbah dengan orang yang lebih rendah. Maka ia memerlukan orang yang lebih tinggi bersifat kasih dan rahmat, sedang yang mengikuti (orang yang lebih rendah) pula bersifat setia dan menghormati. Ketiga, shuhbah dengan yang sama taraf. Maka ia di bina atas asas ithar, yakni mengutamakan orang lain dan kebijaksanaan. Pembagian yang dibuat oleh al-Qushayri ini memberi isyarat bahwa konsep shuhbah dalam konteks ilmu tasawuf dan tarekat mempunyai tujuan yang lebih khusus, bukan sekedar persahabatan atau pendampingan yang bersifat umum atau pada tahap adat kebiasaan saja. Jenis shuhbah yang pertama di atas ialah shuhbah seorang murid yang ingin mendapat bimbingan, tarbiyah dan tarqiyah bersama dengan mursyidnya. Jenis kedua ialah gambaran hubungan antara seorang mursyid yang memberi ta'lim (pengajaran) dan tarbiyah (pendidikan) kepada muridnya. Bentuk yang ketiga ialah shuhbah atau persahabatan yang terjalin antara murid- 
murid yang berada di bawah bimbingan ta'lim dan tarbiyah seorang mursyid tertentu dalam sebuah tarekat tertentu (Nurhasanah, 2018: 42-43).

Didalam shuhbah ada pendidikan, pengajaran, bimbingan yang diberikan mursyid kepada murid. Seperti yang dijelaskan dalam kitab jami'ul ushul fil auliya, bahwa tugas seorang mursyid adalah (Nurhasanah, 2018: 44): (a) Memperjalankan ruh para murid. (b) Menjaga atau membimbing perjalanan ibadah para murid (c) Menyampaikan ruh para murid ke hadirat Alloh SWT.

Menurut Machfoedz komunikasi terapeutik ialah pengalaman interaktif bersama antara perawat dalam kaitan dengan bimbingan penyuluhan islam adalah konselor dan pasien (klien) dalam komunikasi yang bertujuan untuk menyelesaikan masalah yang dihadapi oleh pasien (klien). Komunikasi yang dilakukan oleh konselor dan tenaga kesehatan lain yang direncanakan dan berfokus pada kesembuhan klien (Machfoedz, 2008: 21). Menurut Sheldon komunikasi terapeutik adalah proses yang berkesinambungan antara perawat (konselor) dan pasien (klien) mengembangkan hubungan tidak hanya untuk berbagi informasi tetapi juga membantu pertumbuhan dan penyembuhan (Sheldon, 2009: 7). Dari pemaparan diatas menunjukan bahwa komunikasi merupakan bagian penting dalam menjalin suatu hubungan baik yang dilakukan secara ucapan, tulisan maupun gerakan. Didalam keseharian kita biasa melakukan komunikasi secara langsung dengan menggunakan ucapan juga gerakan atau yang dikatakan dengan bahas verbal dan non verbal. Pada tahun 50-an, ada sosok bernama Albert Mehrabian. Ia menemukan bahwa dampak pesan yang disampaikan bervariasi tergantung bentuk, yaitu 7 persen lisan (hanya ucapan) dan 38 persen vokal (termasuk nada suara [tone of voice]) modifikasi pengucapan tergantung struktur bahasa, dan 55 persen non verbal (Hernandez, 2015: 12). Selain itu dapat disimpulkan bahwa komunikasi terapeutik adalah komunikasi yang dilakukan baik secara verbal, maupun nonverbal yang dilakukan oleh konselor untuk mempercepat penyembuhan dari kliennya

Komunikasi terapeutik dalam bingkai tasawuf ialah proses komunikasi antara klien dan konselor yang mempunyai nilai-nilai penyembuhan (Saam, 2014 : 11), dalam kaitannya ini adalah klien yang merupakan ikhwan atau murid sementara konselor adalah seorang mursyid atau abah Aos.

\section{HASIL DAN PEMBAHASAN}

Pesantren Sirnaraa terletak di Dusun Ciceuri Blok Cisirri Desa Ciomas Kec. Panjalu Kab. Ciamis tepatnya Jalan Raya Panjalu-Kawali. Secara geografis yang terletak diketinggian $731 \mathrm{Mdpl}$ dan berada di kaki Gunung Sawal (1764 Mdpl) 
Jawa Barat. Posisi pesantren Sirnarasa dikelilingi oleh benteng alamiah berupa rangkaian pegunungan, dari sebelah selatan dan timur berdiri kokoh Gunung Sawal yang memisahkan dengan wilayah Galuh, bagian baratnya dibentengi oleh Gunung Cakrabuana yang dahulu menjadi batas dengan kerajaan Sumedang Larang dan di sebelah utaranya memanjang Gunung Bitung yang menjadi batas Kabupaten Ciamis dengan Majalengka yang dahulu merupakan batas Panjalu dengan kerajaan Telaga. Letak pesantren Sirnarasa sangat strategis dan mudah di akses. Luas Pesantren Sirnarasa $\pm 4200 \mathrm{~m}^{2}$ dan Desa Ciomas terletak disebelah barat jalan raya jalur utama Cirebon-Ciamis. Hal ini semakin memposisikan betapa lokasi Pesantren Sirnarasa yang berada di Desa Ciomas Kecamatan Panjalu ini menjadi salah satu tujuan utama bagi mereka-mereka yang bertujuan untuk mencari dan mendalami ilmu agama islam yang berazaskan amalan Thoriqoh Qoddiriyah Naqsabanddiyah (TQN) Pondok Pesantren Suryalaya yang selama ini sudah menyebar kesetiap kota-kota besar di Indonesia dan berbagai negara seperti Malaysia dan Singapura. Yang disamping itu Pesantren Sirnarasa memiliki Lembaga Pendidikan Formal Lainnya. Keadaan Cuaca Pesantren Sirnarasa Sejuk, Jauh dari keramaian, dan bisingnya kendaraan cocok untuk dijadikan tempat belajar dan riyadhoh (latihan atau melatih diri).

Pesantren al-ikhlas didirikan oleh KH. Muhammad Ibrahim dan Ibu Hj. Siti Muslihat tiada lain adalah orang tua kandung abah aos pada tahun 1960. Abah aos remaja menimba ilmu dipesantren gegempalan panjalu, hingga beliau bermukim dan mengemban amanh sebagai ketua majlis ulama kec panjalu, dilain itu beliau juga belajar tarekat qodariyah naqsyabandiyah suryalaya pada abah anom. Atas dorongan pangersa abah anom, pesantren al-ikhlas diganti menjadi pesantren sirnarasa.

\section{Shuhbah Sebagai Komunikasi Terapeutik didalam Pembentukan Karakter}

Shuhbah yang merupakan metode dari sebuah kegiatan yang selalu dilaksanakan oleh seorang individu ikhwan atau jama`ah yang kaitannya menyangkut diri pribadi ataupun kelompok pada Thoriqoh Qoddiriyah Naqsabanddiyah Pondok Pesantren Suryalaya yang bertempat di Pesantren Sirnarasa. Memang memiliki karakteistik yang sama dengan tujuan, fungsi komunikasi terapeutik, juga memiliki ciri-ciri, unsur-unsur dan prinsip-prinsip komunikasi terapeutik.

Seperti yang di kemukakan dalam wawancara dengan Ustadz Daniel Lutfie mengenai apakah pesan yang disampaikan oleh Abah Aos pada shuhbah terdapat efek terapi berikut penyataannya:

"sangat-sangat, yang bapak ketabui kan bapak, sekolah S-2 di komunikasi nah ada yang namanya komunikasi terapeutik dan komunikasi proventif. Komunikasi 
terapeutik itu komunikasi yang menyembubkan komunikasi proventif adalah komunikasi yang keluar dari ruh suci para nabi para mursyid, kalo dulu yang mampu berkomunikasi secara provetif dan terapeutik adalah nabi kalo sekarang guru mursyid abah aos jadi siapapun yang duduk berkomunikasi dengan abah dia sembuh kegalauan batinnya kecemasan hatinya keragu-raguan jadi yakin menenangkan, jangankan bicara duduk saja melihat wajah abah sudah tenang itu namanya komunikasi provetik, keren itu kealo orang semua bisa kaya gitu wab moal aya psikiater dokter moal laku, jadi sebetulnya psikiater sejati yaitu abah.

Maka dari itu dapat di simpulkan bahwa shuhbah merupakan metode baru yang bisa di kategorikan sebagai komunikasi terapeutik karena setiap ucapan pesan yang terlontar dari lisan Abah Aos dalam hal ini sebagai seorang mursyid dan dapat dikatakan sebagai konselor sebab setiap ucapannya memiliki efek terapi bagi siapapun yang mendengarnya.

Untuk membuat penelitian ini lebih terukur maka penelitipun menggunakan angket yang di sebarkan kepada para jama ah, dengan jumlah sampel sebanyak 10 persen jika dari hasil penelitian ruangan yang di gunakan untuk bershuhbah mampu menampung kurang lebih sekitar 150 jama ah maka 10 persen dari 150 orang adalah 15 orang dan dengan memberikan 25 pernyataan baik yang berkaitan dengan shuhbah sebagai komunikasi terapeutik dan juga shuhbah didalam pembentukan karakter.

Adapun skor ideal yang didapat adalah sebagai berikut.

\section{Skor Kriteruim $=$ Nilai Sekala $\mathbf{X}$ Jumlah Responden}

TABEL. 01

SKOR IDEAL

\begin{tabular}{|l|l|}
\hline Rumus & Skala \\
\hline $5 \times 15=75$ & SB \\
\hline $4 \mathrm{X} 15=60$ & B \\
\hline $3 \mathrm{X} 15=45$ & $\mathrm{CB}$ \\
\hline $2 \mathrm{X} 15=30$ & KB \\
\hline $1 \mathrm{X} 15=15$ & SKB \\
\hline
\end{tabular}

Semenatara untuk rating scale yang di dapatkan adalah sebagai berikut.

Tabel. 02

Rating Scale 


\begin{tabular}{|l|l|}
\hline Nilai Jawaban & Skala \\
\hline $61-75$ & SB \\
\hline $46-60$ & B \\
\hline $31-45$ & CB \\
\hline $16-30$ & KB \\
\hline $0-15$ & SKB \\
\hline
\end{tabular}

Oleh karena itu hasil penilaian yang berupa bilang tersebut diubah menjadi sebuah predikat, untuk skor 81 - 100 "Sangat Efektif atau Sangat Setuju", untuk skor 61 - 80 "Efektif atau Setuju”, untuk skor 41-60 “Cukup Efektif atau Cukup", untuk skor 21-40 "Tidak Efektif atau Tidak setuju", untuk skor 0-20 "Sangat Tidak Efektif atau Sangat Tidak Setuju” (Suharsini, 2013: 269).

tujuan komunikasi terapeutik adalah untuk membantu memperjelas dan mengurangi beban pikiran klien, disamping juga dapat mengurangi adanya keraguan serta membantu dilakukannya tindakan yang efektif, mempererat interaksi kedua pihak, yakni konselor dan klien dalam rangka untuk membantu penyelesaian masalah klien dan memengaruhi orang lain, lingkungan fisik dan dirinya sendiri (Muthith, 2018: 306). Seperti yang sudah tertuang diatas maka peneliti juga membuat pertanyaan yang di tuangkan di dalam angket mengenai shuhbah yang juga memiliki kesamaan dalam tujuan komunikasi terapeuti maka berikut hasil jawaban dari angket yang di sebar:

Tabel. 03

Shuhbah Mengurangi Beban Fikiran Dan

Memperjelas Permasalahan Yang Di Hadapi

\begin{tabular}{|l|l|l|l|}
\hline Alternatif Jawaban & Skor & Frekuensi & Nilai \\
\hline Sangat Setuju & 5 & 12 & 60 \\
\hline Setuju & 4 & 3 & 12 \\
\hline Mungkin & 3 & 0 & 0 \\
\hline Tidak Setuju & 2 & 0 & 0 \\
\hline Sangat Tidak Setuju & 1 & 0 & 0 \\
\hline Jumlah & & 15 & 72 \\
\hline
\end{tabular}

Sumber : Angket 2019 
Dapat di lihat pada tabel 03 bahwa nilai dari responden adalah 72 maka dapat dikatakan bahwa skala dari shuhbah mengurangi beban fikiran dan memperjelas masalah adalah sangat baik. Untuk mendapatkan nilai ideal maka akan didapat sebagai berikut.

$$
\text { Skor Kriterium }=5 \text { X } 15=75
$$

Dan untuk mendapatkan nilai persentasinya adalah.

$$
\frac{72}{75} \times 100 \%=96 \% \text { (sangat baik atau sangat setuju) }
$$

Berdasarkan uraian diatas, maka dapat disimpulkan bahwa Jama ah atau Ikhwan thoriqoh Qoddiriyah Naqsabanddiyah Pondok pesantren Suryalaya yang bertempat di Pesantren Sirnarasa berpendapat bahwa ketika melakukan shuhbah dapat mengurangi beban fikiran dan memperjelas masalah. Hal ini seiring dengan tujuan dari komunikasi terapeutik, bahkan menurut Ustadz Jaenudin yang ditemui peneliti menyatakan "sangat setuju babkan mampu menambah wawasan ketika melaksanakan shubbah.

\section{Faktor Pendukung dan Penghambat}

Dalam hasil penelitian yang dilakukan oleh peneliti maka ada beberapa perspektif perbedaan dan beragam mengenai cara menyikapi faktor pendukung dan pengambat.

Jika dari hasil wawancara yang peneliti lakukan dengan Ustadz Daniel maka beliau akan menjawab

"faktor pendukung dan penghambat nyaeta kembali keniat, lamun jalma daek ngalakukun kegiatan shuhbah dengan saenya-enya insya alloh buahna bakalan karasa, tapi lamun jelema niatna macem-macem moal aya perubahan, atau kecil kemungkinanlah. Cuma shuhbah didalam ajaran Thoriqoh itu adalah intinya, anu bakalan ngabuka hijab antara urang jeng Mursyid."

Jika menurut Ustadz Jaenudin Faktor yang mendukung adalah dengan "seringnya kita shuhbah maka akan menumbuhkan karakter itu sendiri didalam perjalanan kedepannya."

Faktor penghambatnya adalah ekonomi, "kalo saja ekonomi sudah tercukupi sudah saja shuhbah terus, walau saur Abah juga ibadah saja nanti juga rizki mah mengikuti, iya itu berlaku untuk mursyid kalo kitakan engga, jadi masih perlu mencari nafkah, kadang ketika shuhbah juga suka kefikiran sama keluarga di rumah."

Dalam wawancara lain peneliti juga menanyakan kepada Ustadz Ali Murtado yang menyatakan bahwa "dengan melihat sosok, akhlak syeikh mursyid jadi ketika sudah shuhbah hati jadi ada cerminan ada gambaran yang baik dan 
energi positifnya luar biasa."

Jadi menurut peneliti dari pernyataan Ustadz Ali menunjukan bahwa dengan seringnya kita shuhbah dan berarti kita sering bertemu dan bersalaman, sering melihat sosok Mursyid akan membuat diri kita bercermin untuk mengikuti jejak akhlak beliau.

Untuk faktor penghambat Ustadz Ali berpendapat, "kembali lagi kepada diri kita, faktor penghalang adalah pengamalan, apa yang di anjurkan tidak diamalkan, itu yang menambah penyakit baik jasmani ataupun rohani."

Kemudian Peneliti mewawancarai Bapak Anwar, dan beliau berpendapat bahwa faktor pendukung beliau menyatakan sangat-sangat setuju shuhbah mampu merubah karakter orang, dengan melihat prilaku beliau, akhlak beliau cara menyambut tamu cara memperlakukan tamu. Dari pernyataannya penulis dapat menyimpulkan bahwa dengan melihat abah disaat shuhbah

Sementara untuk faktor penghambatnya Bapak Anwar berpendapat. "ya namanya kita juga belajar dalam artian ya kalo kita udah pinter ya ga perlu belajar yang penting mah digawe wae di gawe (yang penting bekerja aja bekerja) seperti yang abah bilang orang beriman itu niatnya bagus walaupun terkadang pekerjaannya ada yang tertinggal atau kurang rapih beda dengan orang munafik kalo orang munafik kerjanya bagus tapi niatna ga tau gitu." Dari penjelasan pernyataan yang di dampaikan oleh Bapak Anwar menunjukan bahwa faktor penghambatnya yaitu kembali lagi kepada niat yang kita buat meski kita dalam hal ini masih belajar namun jika niat kita bukan untuk belajar maka semua akan siasia.

Peneliti juga mewawancarai saudara Ega dia berpendapat "bahwa yang menjadi faktor pendukung, pertama adalah rutin, setiap malam jum `at atau jum `at pagi yang penting tiap minggu atau lebih dari itu. Selain itu amaliyah, amaliyahnya harus kita jaga seperti itu. Jadi bukan hanya shuhbah tapi melanggar gitu jadi kurang. Faktor penghambat satu, malas ya rasa malas itu ya ada dan itu harus kita lawan, kedua kurang amaliyah yang menyebabkan kita malas, karen rasa malas itu timbul dari kurangnya amaliyah yang intens, dan yang terakhir kita lupa, lupa dari dzikir yang buat kita lupa kepada Alloh akhirnya kita dapat melakukan kesalahan melakukan dosa."

Faktor pendukung menurut Bapak Odih dalam wawancara mengungkapkan dari melakukan shuhbah.

"yang pertama, kita sebagai ihwan atau sebagai manusia yang banyak dosa kemudian yang mempunyai jiwa kotor berkeinginan memperbaiki diri baik dari segala ucapan tindakan terutama hal-hal yang disampaikan oleh Pangersa Abah 
merupakan contoh atau cerminan bahwa manusia itu akan senantiasa meningkatkan ibadah dalam hal-hal berkarakter atau berkata biasanya kalo misalkan sebelum shuhbah karakternya itu dikatakan tidak baik dengan shuhbah diharapkan lebih baik dengan seperti yang dikatakan oleh abah dengan kalimatkalimat yang menyentuh hati ataupun kalimat-kalimat walaupun kita tidak bertanya kepada Abah tapi Abah sudah mengetahui apa yang ada didalam diri ikwan tersebut. Faktor penghambatnya beliau berpendapat kita kadang-kadang merasa malu untuk shuhbah kenapa, karena ada pribadi kita yang mengatakan malu saya ini banyak dosa sehingga untuk shuhbah teh malu, ada juga faktor orang lain karena merasa dekat berada dilingkungan sini jadi kita menganggap sudah biarkan saja yang jauh, padahal untuk shuhbah tidak boleh seperti itu.”

Dari pemaparan yang di dsampaikan oleh Bapak Odih peneliti mengambil kesimpulan, bahwa untuk faktor pendukungnya adalah dengan selalu bershuhbah melihat akhlak Abah mencontohkan semua yang Abah lakukan, sementara untuk faktor penghambatnya yaitu, perasaan malu yang timbul sebab merasa banyak dosa sehingga terhalang antara kita dengan Abah untuk melakukan perubahan, selanjutnya faktor lingkungan karena merasa sudah berada di satu lingkungan kita berleha-leha.

Sementara menurut Dr. Ucup Pathudin faktor pendukungnya adalah Pasti. Karena pada saat shuhbah, terkadang diajari dan ditunjukkan tentang bagaimana bersikap dan berperilaku sementara faktor penghambatnya yakni "Ada dua. Faktor internal, berupa konsistensi sikap dan perilaku. Terkadang, hal yang ditemukan dan didapatkan pada saat shuhbah, lalu menguap begitu saja. Faktor eksternal, dalam bentuk lingkungan dan pergaualan di luar shuhbah."

Menurut Abah Jagat Atau KH. Budi Rahman Hakim berpendapat faktor pendukungnya yaitu "Dimulai dengan selalu mendapatkan vibrasi dan energi positif jadi ya semakin sering bershuhbah kepada guru semakin kita tertulari sifatsifat amalan-amalan beliau sehingga sangat mempengaruhi karakter kita." untuk faktor penghambatnya adalah "tidak ingatnya kita kepada Alloh sering lalay dan lupa."

Dari pemaparan diatas menunjukan ada beberepa perbedaan pandangan namun juga ada beberapa kesamaan didalam menyikapi faktor pendukung dan juga faktor penghambat seseorang terhadap shuhbah sebagai komunikasi terapeutik didalam pembentukan karakter.

Untuk faktor pendukung misalnya harus intens dalam melakukan kegiatan shuhbah, dan menyimak dengan baik ucapan Abah, lalu memperhatikan akhlak yang dimiliki Abah serta di terapkan, ada juga yang berpendapat kembali ke niat. 
Serta selalu menjalankan amaliyah dengan baik seperti yang di ajarkan oleh Abah.

Sementara faktor penghambatnya ada yang berpendapat tentang faktor ekonomi, waktu, lingkungan, tidak konsistennya didalam melakukan amaliyah dan juga apa yang di contohkan Abah serta tidak mengamalkan amaliyah disertai lupa dengan Alloh SWT.

Maka dari itu untuk mencapai pembentukan karakter yang baik, prilaku yang baik, mampu membentuk kejujuran, mampu menghargai sesama dan lain-lainnya saat kita melakukan shuhbah haruslah menjalankan tiga komponen yang ada didalam shuhbah seperti, istima (berkumpul), ijtima (mendengarkan) dan i'tiba (mengikuti). Pertama kita hadir duduk bersamaan dengan Abah selanjutnya mendengarkan apa yang keluar melalui lisan dan perbuatannya dan selanjutnya menjalankan mengerjakan melakukan apa yang sudah kita dengar dan kita lihat di saat setelah shuhbah tersebut.

\section{PENUTUP}

Shuhbah Sebagai Komunikasi Terapeutik Dalam Membentuk Karakter Jama'ah Thoriqoh Qodiriyah Naqsabandiyah Pondok Pesantren Suryalaya Di Pesantren Sirnarsa.

Apa saja yang terdapat didalam komunikasi terapeutik menunjukan ada didalam pelaksanaan shuhbah bahkan jika di akumulasikan dari 25 pertanyaan yang terdapat pertanyaan mengenai shuhbah sebagai komunikasi terapeutik ada 15 baik menyangkut tujuan komunikasi terapeutik, unsu-unsur komunikasi terapeutik, prinsip-prinsip komunikasi terapeutik, fungsi komunikasi terapeutik, bahasa verbal dan juga bahasa nonverbal maka didapat persentase sebesar 93,2 persen ini menunjukan sangat baik atau sangat tepatnya bahwa shuhbah memang benar memiliki kategori yang ada didalam komunikasi terapeutik.

Sementara untuk shuhbah didalam pembentukan karakter memiliki 10 pertanyaan dan jika dirata-ratakan akan memili persentasi sebesar 92,4 persen yang juga menunjukan bahwa dengan seseorang melaksanakan shuhbah dengan benar-benar maka akan mampu membentuk karakter yang lebih baik dari sebelumnya.

Faktor Pendukung Dan Penghambat Pada Pembentukan Karakter Jama'ah Thoriqoh Qodiriyah Naqsabandiyah Pondok Pesantren Suryalaya Di Pesantren Sirnarasa Didalam Shuhbah Seperti yang sudah dipaparkan didalam pembahasan sebelumnya bahwa faktor pendukung dari keberhasil shuhbah yakni di antaranya adalah. Niat, menjalankan amaliyah, menjalankan tiga komponen utama disaat shuhbah yakni istima (berkumpul), Ijtima (mendengarkan), dan I'tiba 
(mengikuti). Jika tidak berkumpul maka jangankan untuk mendengarkan apalagi mengikuti maka jangan harap mampu membentuk karakter yang baru. Begitupun sebaliknya telah melakukan shuhbah dalam artian telah berkumpul, namun tidak seksama dalam mendengarkan maupun memperhatikan akhlak Abah Aos serta tidak mau mengikuti apa saja pesan-pesan beliau, cara melakukan amaliyah beliau, akhlak, prilaku beliau maka jangan harap pembentukan karakter akan terjadi pada diri.

Sementara faktor penghambatnya adalah kembali lagi kepada diri, seperti misalkan apakah benar kita mampu bersungguh-sungguh mengikuti shuhbah, dan menjalankan amaliayah yang sudah Abah berikan kepada kita, untuk tidak mengingat Alloh, lalai terhadap perintah Alloh, serta terbawa oleh faktor lingkungan di luar shuhbah.

\section{DAFTAR PUSTAKA (Style Jurnal_2.1 Heading)}

Arni, Muhammad. 2011. Komunikasi organisasi. Jakarta: Bumi Aksara

Arwani (eds.). 2002. Komunikasi dalam Keperawatan. Jakarta: Buku Kedokteran EGC.

Ash Shiddiq, KH. Lukman Kamil. 2016. Amaliyah Manaqib TQN PP Suryalaya. Bandung: CV. Wahana Grafika

Bungin, Burhan. 2005. Metodologi Penelitian Kuantitatif. Jakarta: Kencana

Cangara, Hafied. 2003. Pengantar ilmu komunikasi. Jakarta: PT. Grafindo persada

Dinas P \& K. Kamus Besar Babasa Indonesia. Jakarta : Balai Pustaka

Dwidiyanti M. 2008. Keperawatan Dasar: konsep"caring” komunikasi, etika danspiritual dalam pelayanan kesehatan. Semarang : Hasani

Djuarsa, Sasa. 2014. Teori Komunikasi. Jakarta: Universitas Terbuka

Effendi, Onong U. 2004. Dimensi-dimensi komunikasi. Bandung: PT. Remaja Rosdakarya

Hakim, Budi Rahman. 2017. Kanzul arsy jilid 1. Banten: Maktabah Jagat 'Arsy -. 2017. Kanzul arsy jilid 2. Banten: Maktabah Jagat 'Arsy - 2017. Kanzul arsy jilid 3. Banten: Maktabah Jagat 'Arsy

Koeswara. 2006. Teori Kepribadian Psikoanalisis Behaviorisme, Humanistik. Bandung: PT. Eresco 
Lapindus Ira M. 1982. Kamus Umum Bahasa Indonesia. Jakarta: Balai Pustaka Majid. Abdul.2012. Pendidikan Karakter Perspektif Islam. Bandung: PT. Remaja Rosada Karya 2012

Moleong, Lexy J. 2010. Metodologi Penelitian Kualitatif. Bandung: Remaja Rosdakarya.

Muhith, Abdul. dkk. 2018. Aplikasi Komunikasi Terapeutik Nursing \& Health. Yogyakarta : CV. Andi Offset.

Mulyana, Deddy. 2000. Ilmu Komunikasi Suatu Pengantar. Bandung: PT. Remaja Rodakarya 